\title{
Participation of the Community in the Decision-Making Process - Case the Municipality of Pristina
}

\author{
Ferdi Kamberi ${ }^{1}$, Bekim Baliqi ${ }^{1}$ \\ ${ }^{1}$ University of Prishtina \\ Rr. "George Bush", p. n., 10000 Prishtinë, Republika e Kosovës
}

DOI: $10.22178 /$ pos. $37-9$

LCC Subject Category: HM756-781

Received 25.07.2018

Accepted 10.08.2018

Published online 31.08.2018

Corresponding Author:

Ferdi Kamberi

ferdikamberi04@gmail.com

(C) 2018 The Authors. This article

is licensed under a Creative

Commons Attribution 4.0 License

(c) (i)

\begin{abstract}
The community nowadays is defined as a group with a social affiliation, shared value, and interaction that links these members together. Participation of the community in decision making is considered essential characteristics of democracy and particularly of the local government. Thus local governments, through various democratic forms, seek to involve the community to be part of the decision-making process. Various studies and reports in Kosovo do emphasize that participation of the community in policy design and development is low. For this purpose, this paper aims to analyse the community's participation of the community in the decisionmaking process with a particular emphasis on the municipality of Pristina. The research provides a holistic approach to community development in the municipality of Pristina, the level of participation in decision-making processes, forms of communication between local government and the community, and the impact of community development in drafting public policies at the local level. The methodology used here is focused on the different studies and reports on local government and community, and also on quantitative research on public opinion measurement as well. The overall results of this paper emphasize that although there are institutional mechanisms for participation in decision-making, there is a decrease in community participation in decision-making and in the process of drafting and developing local public policies.
\end{abstract}

Keywords: community; local government; Pristina; cooperation; decisionmaking.

\section{INTRODUCTION}

Kosovo does have a unitary local government system - central and local level and has $38 \mathrm{mu}-$ nicipalities in total, which exercise their competencies by the applicable legislation and laws. Community participation in decision-making has a significant role and importance for the community development and its involvement in decision-making processes. The municipality of Pristina during 2017 held only one public hearing meeting with citizens, not respecting the law on local self-government which obliges municipalities to hold at least two public meetings. However, has held other public meetings in specific locations and on various topics including budget discussions, spatial planning at the local level, mandatory public-law acts, as well as other meetings well appreciated by the municipalities. The communication and its forms of communication that are used by the local government of Pristina are the ones that help the community to be informed about the processes of local public policy development and to be better involved in these processes. In this regard, the impact of the community on the development and development of local government policies is exceptionally high and vital for the local government as it contributes to transparency, accountability and good governance as well as to the community because it influences this community that does not feel overlooked or left aside the local government. Therefore, this paperwork addresses the issues of the relationship between local government and the community, communication, cooperation, decision-making and community involvement in local government policies of the municipality of Pristina. The hypotheses presented here are that: There is a decrease in community participation in public hearings due to factors such as disregard of community requirements, lack of 
transport from rural areas, party differences. Also, that: the municipality of Pristina is using contemporary forms of communication when communicating with the community, through social networks, local TVs, billboards, and other media. We verified these hypotheses within the framework of observation of community participation, as well as conducted interviews with citizens in the Municipality of Pristina.

\section{METHODOLOGY}

The methodology used includes several different methods: the method of analysis of the content, which does analyse and elaborate scientific theories on the development of the community and local governance. The statistical method is used to analyse statistics on a budget of the municipality for last three years, allocation of municipality budget by essential segments and compare these statistics with data from some other municipalities. Also the number of public meetings which are regulated by the law for local government. Another used method was an online survey conducted through social media such as Facebook, where 100 responded answered online survey questions using a simple sample of the moment, age - 15 years and above, gender - $60 \%$ male and $40 \%$ female, in Pristina. The survey was carried during May and June 2018 and will continue to contribute the $\mathrm{PhD}$ thesis. The error margins of the survey are expected to be within the range of $+/-3 \%$. The questionary was semi-structured and besides general biographic question, contains other 20 questions mostly closed type and filtered question.

\section{RESULTS AND DISCUSSION}

Pristina municipality has an annual budget increase since the year 2016 that had $65,883,762.00$ Euros and own source revenues $30,000,000.00$ Euros, in 2018 this table is noted to have increased up to $68,757,749.00$ Euros and own source revenues 32,289,607.00 Euro. A relatively high share of this amount goes to various community-based projects around $35 \%$ of the total budget. Based on online research conducted with Pristina respondents, they claimed that the most common form used for community communication by local authorities are social networks with $70 \%$, followed by $39 \%$ e-mail communication, communication through meetings with officials municipal $35 \%$, participation in public hearings by $34 \%$, communication through village councils $32 \%$, through local communities $31 \%$ and official newspapers $30 \%$. When speaking about public meetings, municipalities of the Republic of Kosovo hold meetings that are mandated by law and other meetings that they hold within their competencies and responsibilities. For this purpose, even during our research, about $73 \%$ of respondents said they never participated, $20 \%$ responded that they participated in some of them, $4 \%$ in approximately half of the meetings or every second one and $3 \%$ in most of the meetings. Respondents also stated that community participation has a low impact on the decision-making process in the local government. Whereby $48 \%$ of them says that their participation has little impact on decision-making in the municipality, other $20 \%$ responded that community participation have average impact, $15 \%$ answered saying that it does have high impact, $10 \%$ responded with don't know or refused to answer and $7 \%$ answered that there was no impact at all. As far as the impact of the community on the design and development of public policies at the local level is concerned, their greatest participation is usually on the occasion of their interests or the drafting of municipal budgets. Whereby public consultations are held, taking into account the opinions of community budget allocation for their needs in providing public services, infrastructure, parks, various investments, and in other forms.

\section{Community and local government}

The history of the community is closely linked to ancient civilizations, villages, urban areas, social environments and various locations what date back to old ages. The community is part of the genesis of human history and is assumed to be as old as humanity itself. For this purpose, the community has been seen as a group of people who live and operate in a given location. Today, the community "concerns a particularly constituted set of social relationships based on something which the participants have in commonusually a common sense of identity" [14]. Community unites people, creates a social cohesion between them, has an interaction that and creates common aspects, including values, norms and religion. Here we define community very broadly "as a group or network of persons who are connected (objectively) to each other by relatively durable social relations that extend beyond 
immediate genealogical ties and who mutually define that relationship (subjectively) as important to their social identity and social practice" [8]. From this point of view, we can understand that the community has a specific territory, organized interaction, shared values and beliefs, a sense of social identity that unites the group and cultural similarities. Communities can be micro (small) encompassing mainly small communities such as religious communities, business communities, etc., as well as macro (large) communities that involve national, international or even virtual communities. Hence, the community has even greater empowerment at the moment that empowers their interests, achieved through participation in decision-making in local government. In this segment, the local government considered as an "autonomous system of governance with communities / local communities, established in the narrow parts of the state territory. The development of local self-government is one of the conditions of democracy and the rule of law" [22]. According to M. Weber, multi-party democracy helps to protect society from arbitrary decisions by political leaders and bureaucracy" [4]. Local government is a governing institution exercising authority in a territorially defined area of the country and is considered to be an important factor for encouraging political education and participation in political life as a basis upon which services are organized in such way to meet local needs. It is seen as rational from an administrative point of view, as it ensures efficient delivery of public services, where services are needed under the guidance of the center [15].

\section{Theoretical approaches on community and local government}

Nowadays, the topic about community is one of the most discussed topics worldwide, mainly because the importance that community has to overall social development. Today, most of the studies do refer to the community development as a potential that provides professional and independent support to people's groups, "identifies, together with local people, community problems, increase the empowerment of local people so they can organize themselves in order to solve problems, turns its attention primarily to people struggling with social deprivation and exclusion, contributes to a sustainable community based on mutual respect and social justice, challenges power structures that hinder people's participation and contributes to the socio-cultural development of the neighbourhood by the local people themselves" [6]. Looking closely at the role and importance of the community and its development and local government, we find many theories that deals with these issues, but our focus will be mainly to explain and analyse only some of them. One of the main theories about community is the Theory of Communitarianism that dates back from the time of ancient Greek philosophers such as Aristotle and later other philosophers such: Thomas von Aquin, Hegel, Alexis de Tocqueville, Ferdinand Tönnies, Michael Sandel, Charles Taylor, Michael Walzer, Amitai Etzioni etc. Communitarianism is considered as a social philosophy that focuses on the common good/benefit (of the community), and it is the contrary of other theories such as liberalism that its focus is the individual. Amitai Etzioni in his book "The Spirit of Community", when talking about communitarianism he says that "We are a social movement aiming at shoring up the moral, social, and political environment. Part change of heart, part renewal of social bonds, part reform of public life" [3]. While the Encyclopedia of the Sociology does describes the communitarianism this way "Communitarians, in contrast, see social institutions and policies as affected by tradition and hence by values passed from generation to generation. These become part of the self through non-rational processes, especially internalization, and are changed by other processes such as persuasion, religious or political indoctrination, leadership, and moral dialogues. Besides, communitarianism emphasizes particularism, the special moral obligations people have to their families, kin, communities, and societies" [2]. According to him, the main frameworks of communism are: the moral renewal of society, without puritanism, caring for the right and regulation in society without making the state a police state, saving the family without hurt women's rights, moral education in schools, without indoctrinating the students, new opportunities of community life, without being hostile to one another, giving the person more social responsibility, without limiting individual rights, making claims on individual success in accordance with the purpose united, without forcing people to live in asphyxiation, altruism and self-sacrifice, creating a new moral, social, and public arrangement that is built on the basis of fundamentally renovated communities, without puritanism and op- 
pression" [10]. Another theory which is closely related to community, development and local government is the Theory about theoretical perspective on governance and power. Parson developed this theory and according to him, "political organization as functionally organized about the attainment of collective goals, i.e., the attainment or maintenance of states of interaction between the system and its environing situation that are relatively desirable from the point of view of the system" [12]. From a systems point of view, "the "polity" exists to perform specific functions and meet certain needs generated by society. In particular, it exists to provide a means of attaining "desirable" collective goals by being the site of collective decision making. According to functionalism, modern forms of government have four main purposes: planning and directing society, meeting collective social needs, maintaining law and order, and managing international relations" [12]. This theory has to do with the decision-making process and the cases when collective actions should be a priority toward individual or clan actions. Affirmed goals that Parsons highlighted shows that through the citizen / community decision-making process, collective goals could be easily achieved and also meeting the needs of society as well, in which processed citizens / community actively participate. Parsons goes further by dividing the society into four equal interacting units, which are functional problems and presented them as AGIL (abbreviation). He thinks that every society faces these four major problems: Adaptation, Goal Achievement, Integration, and Latency. According to him if these parts are functional, then we have a society, a community that is functional, on the contrary, we have a dysfunctional society or community. A third theory we speak about in this paperwork is Theory of ladder of citizen participation. This theory is presented Shery Arnstein (1969), she came with the idea of "Ladders of participation", which theory was very functional in practice as exploited weak ones used it up to those who have power and control. In her theory, Arnstein suggested eight "rungs" of participation, within which we have three main categories or degrees (nonparticipation, degrees of tokenism and degrees of citizen power)" [5]. According to this theory, citizen participation in the decisionmaking process is important because creates a critical voice to local governance and that through participation, citizens can closely monitor the work of elected people at the level of local government. In her theory she highlights 8 rungs (ranging from 8 to 1 and not from 1 to 8 ) in three different degrees or categories. According to Arnstein, the level of active citizenship includes three levels: 8. Citizen Control, 7. Delegated power and 6 partnership. The next step is to create an active citizenship image that includes three other rungs: 5. Placation, 4. Consultation and 3. Informing. And finally, there is also the degree of passive citizenship that has two rungs: 2 . Collective Therapy and 1. Manipulation. Based on this theory, which is more the theory of public policy and can be classified into the theory of political sociology, it turns out that the first two levels represent an active citizen who monitors the work of their representatives and their decisionmaking significantly affects the improvement of life of citizens. Meanwhile, the level of passive citizenship has to do with the nonparticipation of citizens in these processes, which causes their representatives to have the possibility of manipulation and a kind of therapy that she calls collective therapy.

\section{Community and local governance in Kosovo}

Public policies "in the general sense" are seen as formal and legal decisions of government no matter at which level. Such policies are linked that links goals, actions and outcomes. Public policy deals with observing decisions from their inception, as ideas up to their evaluation, correction, completion or even implementation" [1]. On the other hand, the community during the process of participating in drafting public policies at the local level may have impacts that may also change the position of the community itself. Parsons pointed out that the community is "a collectivity, whose members share a common territorial area as their base for everyday activities. According to Ferdinand Tönnies, the community can be defined as a kind of natural organ of a social group, whose members are joined together by the sense of belonging, which sense is created by daily contacts and interaction that covers a wide range of human activities" [1]. In the sociological context, the community does have social interaction and planning, because the common values, sense of being part of the community, social belonging and social identity do reinforce their relations in the major processes of drafting policies at local level. Therefore, "community development is characterized by: A focus on empowerment and participation of marginalized groups in decision- 
making that impacts on their lives and communities A collective rather than an individual approach to tackling problems A social analysis and understanding of the causes of poverty and disadvantage and a commitment to equality and social justice" [13]. The relation between community and local government in Kosovo is meaningfully and of vital importance, because firstly reflects citizens participation (communities) in decision-making at the local level and secondly gives a strong signal that the community is an important partner for further development of local self-government. In the most cases, the community in Kosovo is understood or perceived as "ethnic minority" by referring to the local communities that live and operate in Kosovo. As a broader term of the community in the sense of the community or social group that live and operate in a certain location, Kosovo's legislation on local self-government refers to as "citizens". The Law on Local Self-Government in the descriptions states that "Community means a group of communities belonging to the same ethnic, religious, or linguistic group" [19], and the term "citizen" in the most cases is defined or it refers to the context of the community as a community or group of people having values or feelings of social and identity affiliation. Whereas, Law on protection and Promotion of the rights of communities and their members in Kosovo, article 1, paragraph 1.4 , says that "communities are defined as national, ethnic, cultural, linguistic or religious groups traditionally present in the Republic of Kosovo that is not in the majority. These groups are Serb, Turkish, Roma, Ashkali, Egyptian, Gorani and other communities. Members of the community in the majority in the Republic of Kosovo as a whole who are not in the majority in a given municipality shall also be entitled to enjoy the rights listed in this law" [19]. In regard of local governance in Kosovo, "the municipality is the basic unit of local self-government" [19]. The municipality structure is mayor, the municipal assembly and local administration. Municipalities, within their responsibilities and competencies, are obliged, especially in the case of public meetings, to be open and transparent to the general public so that also the public (citizens) presents issues of outside and public interest. Which is guaranteed in the framework of the European Charter for Local Governance, but also with the Law on Local Government, which obliges municipalities to hold public meetings at least twice in the year. Although the Law on Local Self-
Government also specifies other local decisionmaking mechanisms such as civic initiatives, local referendums, public consultations, public meetings, budget participation, and consultative committees, which enable citizens (community) to make easier and practical decision-making. Currently, Kosovo has a total of 38 municipalities, the largest municipality is the municipality of Pristina, and the smaller one is the municipality of Partes. The community and local government in Kosovo have a pretty good relationship because the community is the one that contributes to the development of local democracy, while local governance through citizen orientation has an impact on community development as well as in improving the citizen's life quality.

\section{The role of local structure in the development of the community}

The municipality of Kosovo is the capital of Kosovo, with a surface of $572 \mathrm{~km}^{2}$. According to the latest registration in 2011, Pristina has a population of 198, 89 inhabitants, among which 194,452 are Albanians, 21565 Turks, 557 ashkali, 430 Serbs and 1082 others. During age-group we have 0-18 years old about 68.830 and 18-65 years old about 109.892" [24]. As far as the structure, the municipality of Pristina does have the executive - the mayor, the municipal assembly that does have in total 51 assembly members and local administration, which have two different components: a) political component with municipal directors and b) civil servants which are elected independently as defined at the law for civil servants in Kosovo. Within the responsibilities of the mayor and the assembly, which is also the highest organ in the municipality according to the Law on Local Self-Government, drafts and promotes policies for the development of the community and their life quality in the territory of Pristina municipality. Such is also clearly expressed through the communication with the public / community and developing various projects for the community, so the citizens/community shall have a better and more qualitative life. Based on the data, a projected budget of the municipality of Pristina for last three years is as below (Table 1).

If we look deeper into details, we see that budget of Pristina municipality is significantly higher than other municipalities, taking the consideration the fact that Pristina is the capital of Kosovo. 
Table 1 - Projected budget of Pristina municipality and own-source revenues" [24]

\begin{tabular}{|c|c|r|}
\hline Year & $\begin{array}{c}\text { Annual projected } \\
\text { budget }\end{array}$ & $\begin{array}{c}\text { Own-source reve- } \\
\text { nues }\end{array}$ \\
\hline 2016 & $65,883,762.00$ & $30,000,000.00$ \\
\hline 2017 & $67,272,999.00$ & $31,122,387.00$ \\
\hline 2018 & $68,757,749.00$ & $32,89,607.00$ \\
\hline
\end{tabular}

For the year 2018, the municipality of Pristina has approved a "budget of 72,273,904.00 euro. From this budget, 24,954,207.00 Euros are allocated for capital investments or in other figures, $35 \%$ of the total budget" [16]. At the same time, this also indicates the development of the community as we can see the municipality of Pristina, allocated a significant portion of its budget for this purpose, making the community to have a more qualitative life and also bringing them closer to the citizens.

\section{Forms of communication between local authorities in Pristina and community}

Communication itself is a process that connects people, is like a bridge, it is a process of conveying a message that involves sender and receiver, two parties or subjects when at least one of them wants to communicate. Communication is a process that connects people, it is the process of sending and receiving messages and is developed at least between the two subjects, respectively when one of them wants to communicate. Communicating "means to convey the information you have in mind, the information that the communicator, the one that initiates the communication or the messenger conveys to others: knowledge, memories, parables, judgments, desires, feelings, etc" [18]. Therefore, for this purpose we can conclude that communication is part of identity, is art itself, is a process that connects people and empowers social cohesion in the society. The language as another part of communication in the psychological context. A language consists of symbols that convey meaning, plus rules for combining those symbols, that can be used to generate an infinite variety of messages" [26], which means that the language is the main element of communication although communication can be in different forms and ways such as verbal, nonverbal, cultural, intercultural, public, personal and interpersonal, etc. The main purpose of communication is to exchange ideas, information's and messages from one to the other party.
In this context, also local government communicates with the community (general public) through different media such written, electronic, social networks, local television, billboards, flyers etc. During a survey conducted with citizens of the municipality of Pristina related to this paperwork, on the question: In what forms do you communicate with the authorities of the municipality about issues of public interest? They answered as follows (Figure 1).

Based on the diagram above, we can see the most commonly used form of communication with the community by local authorities is via social networks with $70 \%$, followed by $39 \%$ communication via e-mail exchange, communication through meetings with municipal officials $35 \%$, participation in public meetings with $34 \%$, communication through village councils $32 \%$, through local communities $31 \%$ and through official papers $30 \%$. This research through with is represented by a small sample, however, does reflects Kosovo's reality, because studies claim that Kosovo has a new population structure of around $60 \%$ of youth, considered to be the youngest population in Europe and when talking about use of internet (social media), Kosovo is the leader in the Balkans with the number of users and population. Studies argue that "regarding the low confidence interval, the summary of answers with an answer "Yes" means that internet penetration in the household is at least $84.81 \%$ or 251.962 households (according to households according to the latest civilian registration of the year 2011). In this context, the European Union has published a report stating that $84 \%$ of households in developed countries have access to the internet from home. It is worth mentioning that UNDP has published the report Kosovo's Mosaic in 2012 (data's collected in February 2012), findings say that the city with the highest percentage of internet coverage is Pristina with $82 \%$, followed by Mitrovica with $76 \%$ " [25].

Therefore, is not a surprise that the majority of Kosovo's population, mostly young people use social media and networks and get informed or they do communicate with local government through these channels of communication? This study goes further stating that "Kosovars are the greatest users of the internet with about $86.7 \%$ of the population who surf internet daily. On the other hand, Eurostat points out that in $84 \%$ of citizens of European countries use the internet daily. 
In what ways do you communicate with the authorities of the municipality about issues of public interest?

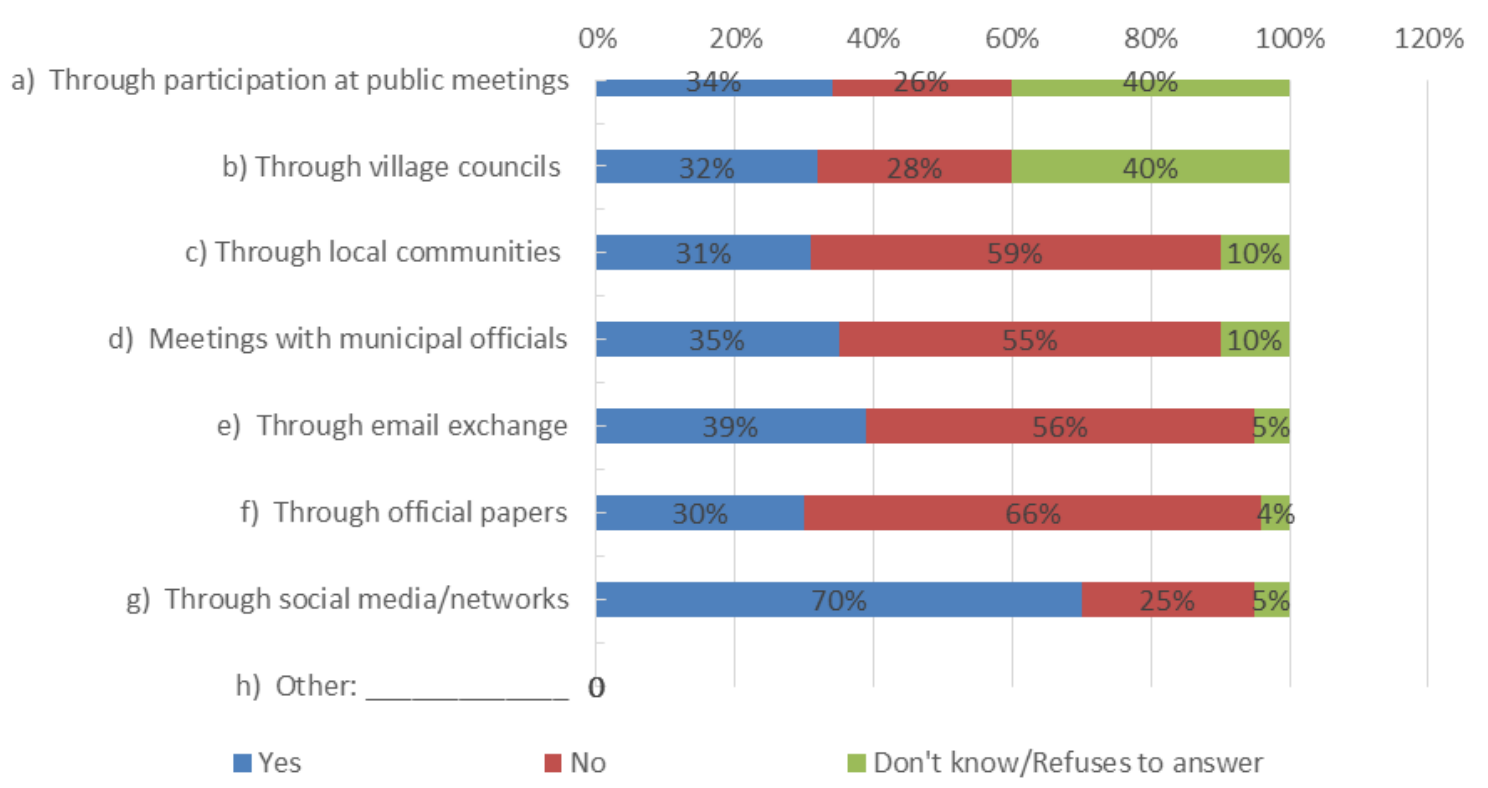

Figure 1 - Opinions of the respondents from Pristina municipality about ways of communication in their municipality concerning issued of public interest [9]

Notes: The survey was conducted in the municipality of Pristina with 100 respondents, $60 \%$ male and $40 \%$ females, during June 2018. This research is part of the research project of the subject of the doctoral dissertation with the topic "Community Development and Local Governance - Comparative Study of Municipalities of the Pristina region".

According to the data derived from the census, the average number of family members per household is 5.8. Most of youth internet users, use English as a primary language, while the Albanian language is used as a primary language for group age 40-59. Female users use Albanian and English more than male users. The users of age from 20-29 years old, as the ones who use mainly German as the primary language" [25]. For this purpose, lately, the central institution, which is also the central authority to monitor the local government is the Ministry of Administration of Local Government, has installed the intranet system and they did update the municipalities webpages, which offers the possibility of online telepresence or the possibility to broadcast online meetings of respective municipal assembly, in order to establish a better communication between local government and the community. Beside this, there also exists other platforms of communication with the community, for example, we have such platforms at the municipalities of Pristina and Gjakova, which are installed with the help and support of OSCE mission" [21], such a platform helps the commu- nity/citizens to express their opinion/ideas about projects and also to express their needs. This fact speaks about the role and the eagerness of the local government to improve and develop community in close cooperation with different partners on the issues concerning the development of the community.

\section{(Non-) Participation of the community in decision- making}

Speaking of the participation of the community in decision-making is good to explain that decision making as a concept is attributed to the participation of different groups of interest in a given issue within local policies. In fact, "decision making is carried out by a wide range voluntary association while the opinion is derived by local groups of interest" [18]. Decision making is a complex and multidisciplinary process because is related to various important issues of local government and in particular to the relationship between citizens and representing bodies/institutions. Therefore, involvement of the community in the decision-making process it 
strengthens the relationship between local government and community for a number of reasons, first, decision making as process makes the community to be more flexible in drafting local policies, secondly, when the community is involved in decision making, the local government is more transparent, more accountable and above all does create the idea of a good governance, thirdly, during such cooperation's between community and local government an interaction between these parties will be created which makes the community to develop and the same (community) in the future would "reward" the local government with its vote. The involvement of local community in the decision-making processes is part of direct democracy, which fosters the citizen's trust toward local government institutions. Also, "the right of citizens to participate in decision-making processes at the local government level does represent the principle of democratic state and precondition for transparent and accountable work of local government and institutions. This means every citizens activity with the purpose to get involved in the approving and implementing public policies at local level (submitting requests for free access to information, signing petitions, participating at public meetings with citizens, taking initiatives to solve problems that affects local population/citizens, clear actions and various forms of protesting to raise the voice against irregularities at local government level etc)" [23]. Data from Ministry of Local Government and Administration reports for the year 2017, shows that citizens relatively participate in decision making, especially during public meetings, public consulting meetings, meeting with different municipal committees and participation in the budget, as follow (Figure 2).

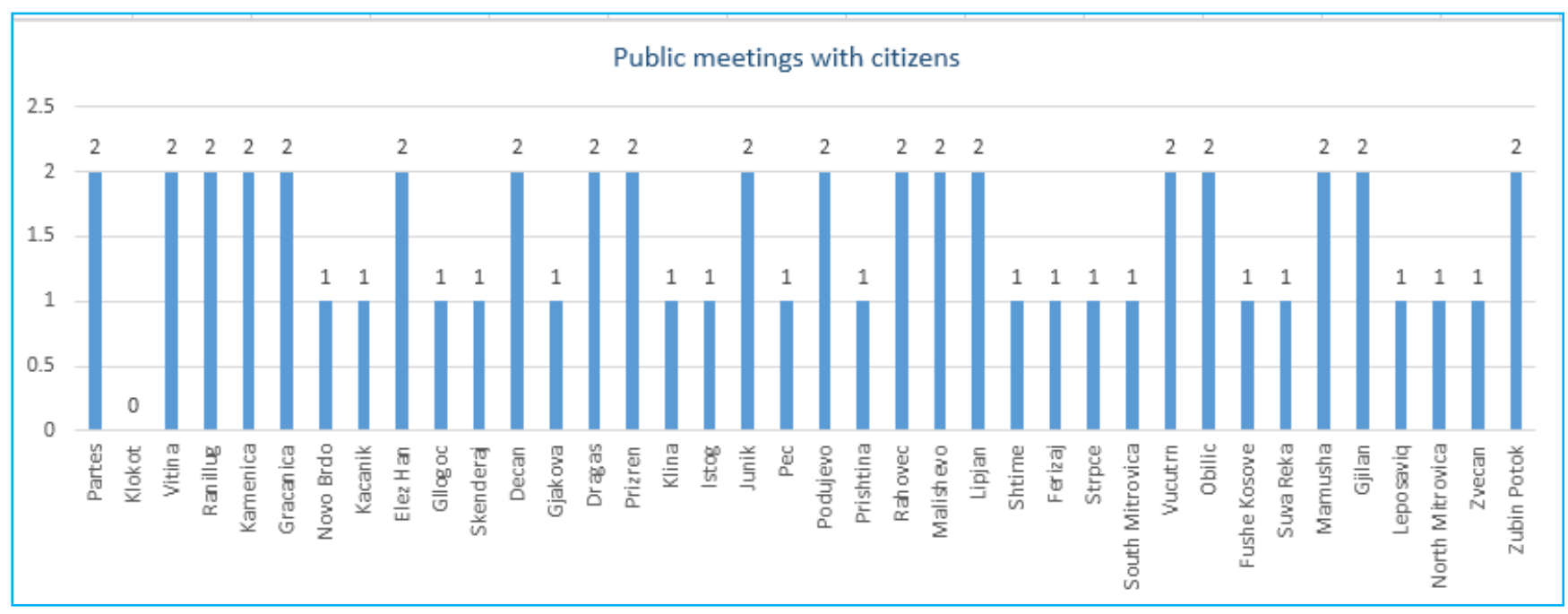

Figure 2 - The number of public meetings in municipalities as Law obliges them on Self-Government [24]

Law on Local Self-Government obliges municipalities to "hold periodically, at least twice a year, a public meeting at which any person or organization with interest in the municipality may participate. The date and place of the meeting shall be publicized at least two weeks in advance. One of the meetings shall be held during the first six months of the year" [20]. Therefore, as we can see from the chart, most of the municipalities have met this legal obligation, with the exception the municipality of Klokot with no single public meeting during the year 2017. While the municipalities of Novo Brdo, Kaçanik, Gllogovc, Skenderaj, Gjakova, Klina, Istog, Pec, Pristina, Ferizaj, Shterpce, Mitrovica (South and North), Fushe Kosove, Suha Reka, Zveçan and Leposavic each have held only one public meeting with citizens in the year 2017. Beside those meeting "municipalities have held also other additional meeting with its citizens, in given locations and on different issues such: discussions on budget, spatial planning on local level, mandatory draft proposals for public discussion and other meetings evaluated by municipalities" [24]. In general, we can see those very few citizens participates in these meetings. In order to validate this hypothesis, within our survey we have included one question that is related to this issue: How often do you participate in public meetings at your municipality, as we have received these results as follows (Figure 3). 


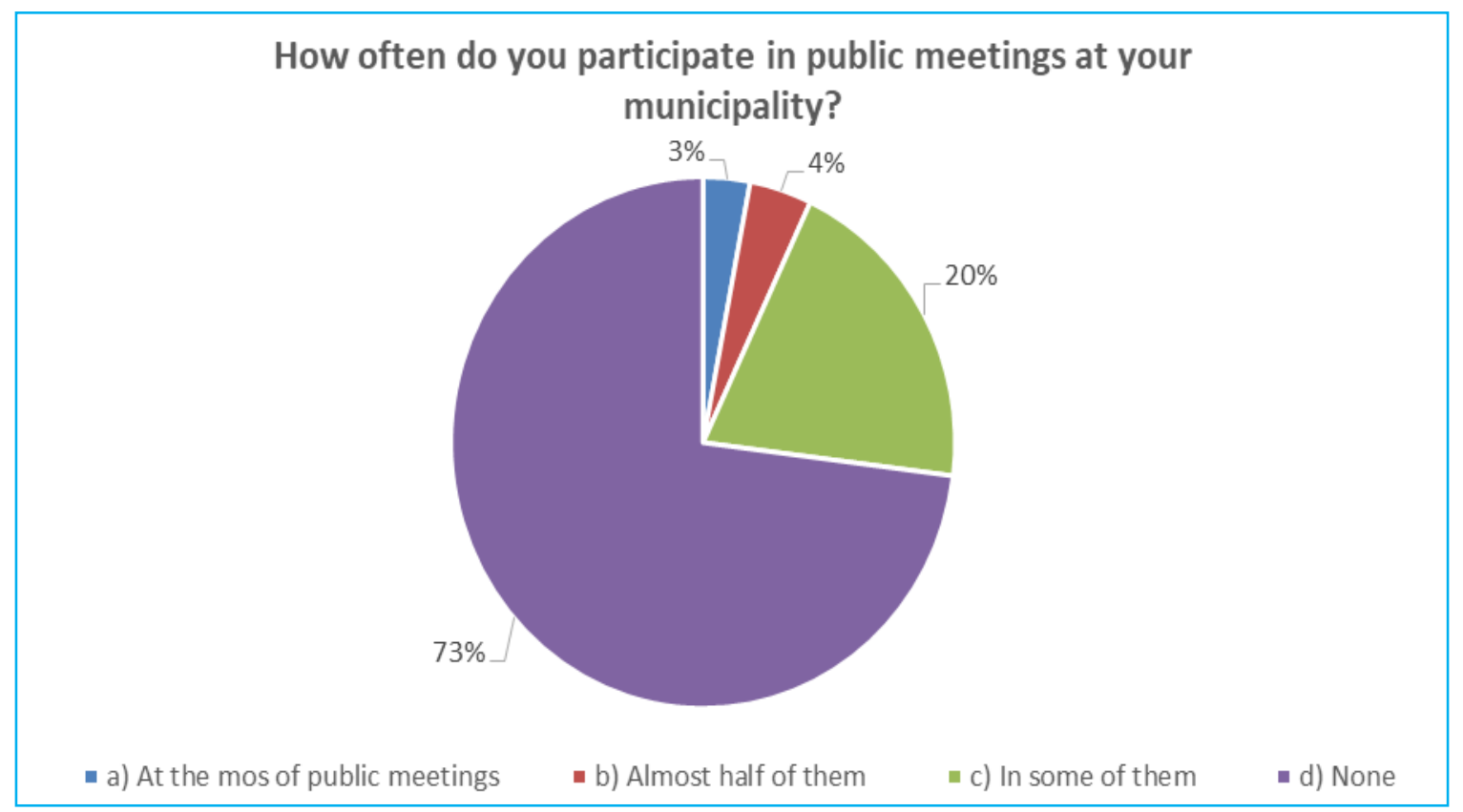

Figure 3 - Opinion of respondents about participation in public meetings at local level [9]

Notes: The survey was conducted in the municipality of Pristina with 100 respondents, $60 \%$ male and $40 \%$ females, during June 2018. This research is part of the research project of the subject of the doctoral dissertation with the topic "Community Development and Local Governance - Comparative Study of Municipalities of the Pristina region".

Based on this chart we can assume that despite the fact that there are legal mechanisms for community participation in decision making, the majority of respondents said that they don't participate in public meetings, fact that corresponds to the reality, because also the data published by municipalities supports this saying that the participation of citizens is low. For sure, there is a need to see the impact of some factors such: disregarding citizens opinion, not supporting of project which they (citizens) think as necessary to improve the quality of their lives, unnecessary political pressure, the negligence of municipal bodies to adequately address citizens opinion(s), citizens lack of time to participate in such meetings, not good transportation in deep rural areas which makes them not to participate in these public meetings and many other factors. Respondents of our survey do support these factors with their answers in following questions, according to them (Table 2).

The table shows that about $40 \%$ of respondents have answered that their opinions are not taken much into consideration, compared with only $5 \%$ of them who said that their opinions are taken highly into consideration.
Table 2 - Opinions of respondents from Pristina municipality about to what extent their opinion has been taken into consideration by local government, $\%$ [9]

To what extend your opinion have been taken into consideration by municipal authorities?

\begin{tabular}{|l|c|}
\hline Very much & 5 \\
\hline Average & 17 \\
\hline Little & 40 \\
\hline Not at all & 28 \\
\hline Don't know/refuses to answer & 10 \\
\hline
\end{tabular}

Notes: The survey was conducted in the municipality of Pristina with 100 respondents, $60 \%$ male and $40 \%$ females, during June 2018. This research is part of the research project of the subject of the doctoral dissertation with the topic "Community Development and Local Governance - Comparative Study of Municipalities of the Pristina region".

They also claimed that even they do participate in decision making still decision making have a low impact on changes or developments, as follows (Figure 4). 


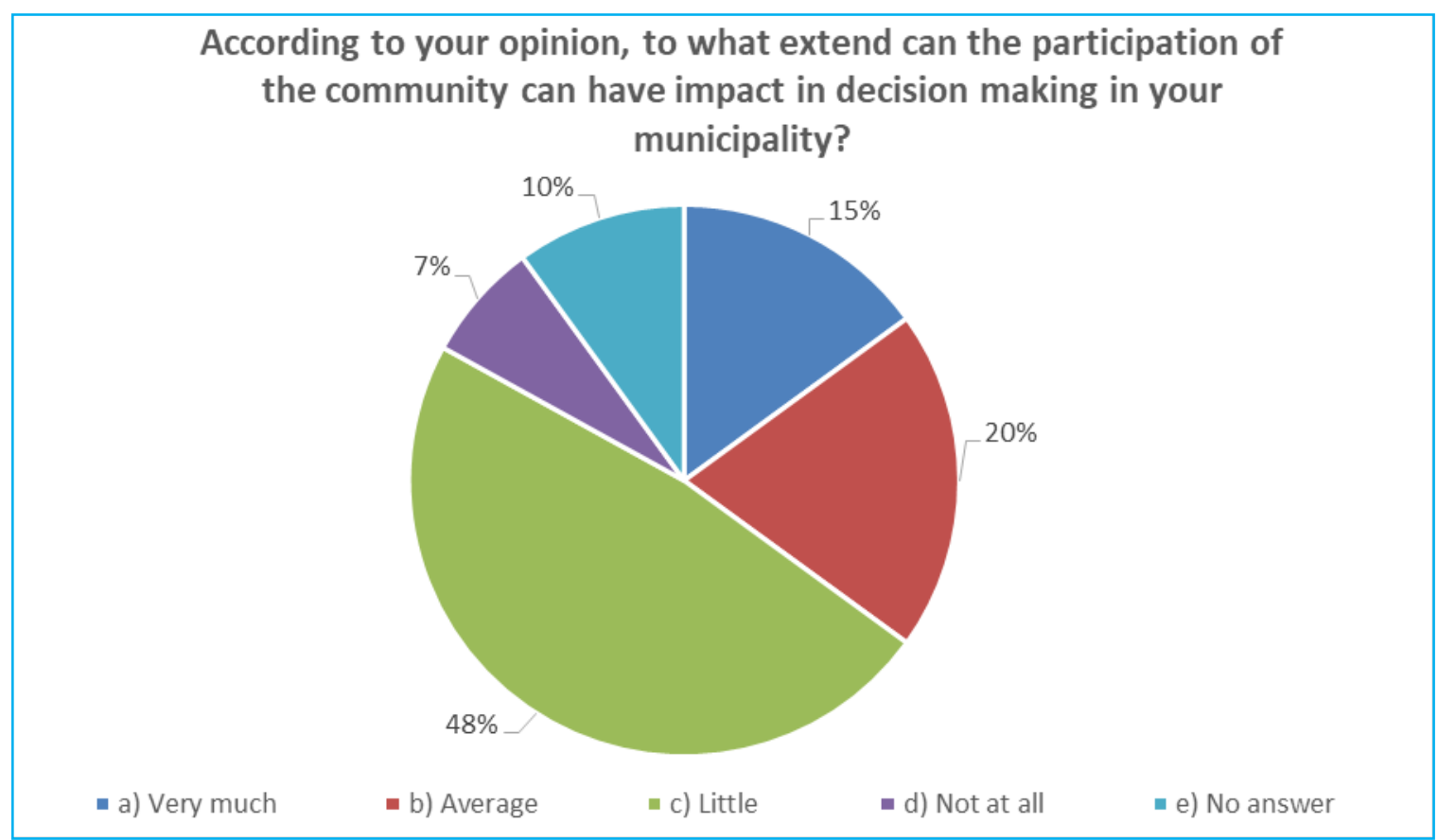

Figure 4 - Opinion of the respondents about participation of the community in decision making [9]

Notes: The survey was conducted in the municipality of Pristina with 100 respondents, $60 \%$ male and $40 \%$ females, during June 2018. This research is part of the research project of the subject of the doctoral dissertation with the topic "Community Development and Local Governance - Comparative Study of Municipalities of the Pristina region".

This chart shows that respondents think that even if they participate in local governments meetings there is no significant impact on decision, despite existing mechanisms, therefore the majority of respondents have choosed the option Little. This fact has a correlation with above mentioned factors because it reflects community's opinion on function of trust in local government regarding the decision making. Perhaps the community has participated occasionally in these public meetings and have expressed their opinions which haven't been taken into consideration, so this reaction of disappointment and lack of will to participate in these meetings is normal.

\section{CONCLUSIONS}

Based on what we have elaborated so far, we can conclude that the system of local government in Kosovo is one level (central and local level) and it is in accordance with the legislation for local selfgovernment, there exist the mechanisms of direct democracy that involves citizens to be part of designing and developing public policies. We have seen that the forms of communication between the local government and the community are mainly through: local TV, billboards, leaflets, social networks, municipal website and other. Fi- nally, some municipalities, including the municipality of Pristina, have also established platforms for consultation with the community for issues of general public interest. Therefore, this communication and consultation have made the community, in one way or another, to be part of the decision-making process, although as we have seen, the participation of the community in public meetings is meager not only in the municipality of Pristina, but also in other municipalities. Local government according, to the law on local selfgovernment should organise at least 2 (two) meetings with the community within a year, while other meetings will enrich the reports of each municipality, whereas the municipality of Pristina in the year 2017 has realised only one of this kind. We have also seen that the community itself has expressed appreciation for its participation in these processes, although they have claimed that they are not participating due to some different factors. Therefore, we can generally say that various capital investments by the Municipality of Pristina in different projects can also result in a more proactive participation of the community in decision making, thus creating a higher culture of decision making and an active citizenry and on the other hand, local government can influence citizens to have quality services and improve the quality of life. 


\section{REFERENCES}

1. Baliqi, B. (2017). Politikat Publike dhe Qeverisja. Retrieved from http://www.kas.de/wf/doc/kas_50688-1522-33-30.pdf?171115103925

2. Borgatta, E., \& Montgomery, J. R. (2000). Encyclopedia of Sociology (2nd ed.). New York: Macmillan Reference.

3. Crawford, A., \& Etzioni, A. (1996). The Spirit of Community: Rights, Responsibilities, and the Communitarian Agenda. Journal of Law and Society, 23(2), 247. doi: 10.2307/1410419

4. Giddens, A. (2004). Sociology. Tirana: Fondation Soros - Çabej.

5. Hartay, E. (2011, October). Citizen participation. Best practices in the western Balkans and the European Union. Retrieved from http://www.kcsfoundation.org/repository/docs/03_03_2014_3974014_KCSF_2011_Best_practi ces_on_Citizen_Participation_in_WB_and_EU.pdf

6. Hautekeur, G. (2005). Community development in Europe. Community Development Journal, 40(4), 385-398. doi: 10.1093/cdj/bsi083

7. Institute for Development Policy. (2017). Analizë e Politikave 06/2017. Investimet kapitale në katër komuna të Republikës së Kosovës. Retrieved from http://indep.info/wpcontent/uploads/2017/05/Analize-e-investimeve-kapitale-ne-komuna-1.pdf

8. James, P., Nadarajah, Y., Haive, K., \& Stead, V. (2012). Sustainable communities, sustainable development. Other paths for Papua New Guinea. Retrieved from https://www.researchgate.net/publication/265162446_Sustainable_Communities_Sustainable_ Development_Other_Pathways_for_Papua_New_Guinea

9. Kamberi, F. (2018). Community Development and Local Governance - Comparative Study of Municipalities of the Pristina region: results of pilot project.

10. Kiçmari, S. (2008). The idea, Purpose and Practical Implemenetation of Communitarian Theory. Studime Sociale, 2(2).

11. Kosovo Local Government Institute. (2017). Municipal Profiles. Retrieved from https://www.klgiks.com/repository/docs/Municipal_profiles.pdf

12. Little, W., Vyrain, S., Scaramuzzo, G., Cody-Rydzewski, S., Griffiths, H., Strayer, E., Keirns, N., ... McGivern, R. (2016). Introduction to Sociology. Retrieved from https://opentextbc.ca/introductiontosociology/chapter/chapter17-government-and-politics

13. Lynam, S. (2006). Community Development and Public Policy. Retrieved from http://www.combatpoverty.ie/publications/CommunityDevelopmentAndPublicPolicy_2006.pd $\mathrm{f}$

14. Marshall, G., \& Scott, J. (2009). A dictionary of sociology. Oxford: Oxford University Press.

15. McLean, I., \& McMillan, A. (2009). The Concise Oxford Dictionary of Politics. Oxford: Oxford University Press.

16. National Endowment for Democracy. (2018). Prishtinë 2018. Retrieved June 1, 2018, from http://investometri.com/sq/prishtine-2018

17. OSCE. (2013). Procesi i Zhvillimit të Buxheteve Komunale në Kosovë: Vlerësim krahasues i proceseve të vitit 2012 dhe 2013. Retrieved from https://www.osce.org/sq/kosovo/102216?download=true

18. Pajaziti, A. (2010). Fjalor Sociologjik. Skopje: Logos.

19. Ligji për Mbrojtjen dhe Promovimin e të Drejtave të Komuniteteve dhe Pjesëtarëve të tyre në Republikën e Kosovës (Kosovës), 13.03.2008, No 03/L-0.47. Retrieved June 1, 2018, from https://gzk.rks-gov.net/ActDetail.aspx?ActID=2531 
20. Ligji për Vetëqeverisjen Lokale (Kosovës), 20.02.2008, No 03/L-040. Retrieved June 1, 2018, from https://gzk.rks-gov.net/ActDocumentDetail.aspx?ActID=2530

21. Platforma Digjitale për Pjesëmarrje Publike. (2018). Prishtina. Retrieved June 1, 2018, from https://platformadigjitale.com/Prishtina

22. Pollozhani, B., Dobjeni, E., Stavileci, E. \& Salihu, L. (2010). E drejta administrative: Aspekte krahasuese. Tetovo: Asdren.

23. Qendra për zhvillimin e organizatave joqeveritare. (2013). Pjesëmarrja e qytetarëve dhe bashkëpunimi mes sektorit civil dhe vetëqeverisjeve lokale në mal të zi dhe shqipëri. Retrieved from https://www.crnvo.me/sites/crnvo/files/article_files/ucesce_gradjana_alb_4_web.pdf

24. Republic of Kosovo. Ministry of Local Government Administration. (2018, March). Report on the functioning of municipalities of the Republic of Kosovo. Retrieved from https://mapl.rksgov.net/wp-content/uploads/2018/03/RAPORTI-Versioni-i-fundit-23.03.2018-ANGLISHT.pdf

25. Shoqata për Teknologi të Informacionit dhe të Komunikimit të Kosovës. (2013). Depërtimit dhe Përdorimi i Internetit në Kosovë. Retrieved from http://www.mfaks.net/repository/docs/STIKK_raport_alb_2013_short_web.pdf

26. Weiten, W. (2011). Psychology: Themes \& Variations (9th ed.). Belmont: Wadsworth Cengage Learning. 